\title{
STUDI PENGGUNAAN ANTIBIOTIKA PADA NEONATUS DI NICU RSAL DR. RAMELAN SURABAYA
}

\author{
Victoria Yulita Fitriani \\ Kelompok Bidang Ilmu Farmasi Klinis, Fakultas Farmasi, Universitas Mulawarman, Samarinda \\ e-mail: vloved29@gmail.com
}

\begin{abstract}
Neonatal sepsis and nosocomial infection are the most common diagnosis of neonatal infections. Selections of antibiotics in neonatal infection should be based on type of bacteria, antibiotics dose and safety in neonates. The aim of this study was to explored type of antibiotics used in Neonatal Intensive Care Unit. Researchers conducted a prospective study of antibiotics used at Dr. Ramelan Navy Hospital neonatal intensive care unit Surabaya. From November $26^{\text {th }} 2007$ to January $26^{\text {th }} 2008,94$ patients (5 preterm neonates and 89 term neonates) were included in this study. Demographic data, antibiotics used, relevant medical histories, laboratory data was recorded prospectively at the wards. Charts for all cases were reviewed. Early antibiotic use was defined as therapy within 72 hours of life. The most frequently used empiric antibiotic regimens were ampicillin sulbactam with gentamicin (60.2\%), ampicillin sulbactam (30.1\%), ceftriaxone (6.5\%), ampicillin sulbactam with amikacin (1.1\%), ampicillin sulbactam with ceftriaxone (1.1\%), gentamicin with ceftriaxone (1.1\%). Late antibiotic events also occurred in neonates. Fourty eight point four percent of late antibiotics events were used of ceftriaxone. Antibiotics are prescribed appropriately but earlier discontinuation or switches, which may be complicated either by the inability to confirm causative organism or patient's condition that showed no improvement, should be practiced.
\end{abstract}

Key words: Neonatus, antibiotic

\begin{abstract}
ABSTRAK
Diagnosa infeksi pada neonatus umumnya berupa sepsis neonatorum dan infeksi nosokomial. Pemilihan antibiotika pada kondisi tersebut perlu didasarkan kepada jenis bakteri yang umumnya terlibat, dosis antibiotika dan tingkat keamanan pada neonatus. Penelitian ini bertujuan untuk mengeksplorasi jenis antibiotika yang digunakan pada pasien neonatus. Penelitian ini merupakan penelitian prospektif dengan melakukan pengamatan secara langsung selama 3 bulan di NICU RSAL Dr. Ramelan Surabaya. Peneliti mengobservasi pasien secara langsung dan mengambil data pemakaian antibiotika melalui rekam medik. Semua pasien neonatus yang menjalani rawat inap di NICU periode (Oktober - Desember 2007) disertakan sebagai sampel penelitian. Hasil penelitian di dapat antibiotika untuk penanganan tahap awal yang sering digunakan adalah kombinasi ampisilin sulbaktam dengan gentamisin $(60.2 \%)$, ampisilin sulbaktam (30.1\%), ceftriaxonee (6.5\%), kombinasi ampisilin sulbaktam dengan amikasin (1.1\%), kombinasi ampisilin sulbaktam dengan ceftriaxonee (1.1\%), kombinasi gentamisin dengan cetriaxone $(1.1 \%)$. Antibiotika untuk penanganan tahap akhir adalah ceftriaxonee (48.4\%), kombinasi ceftriaxone dengan amikasin (25.6\%), amikasin (9.3\%), ampisilin sulbaktam (4.7\%), kombinasi ceftriaxone dengan gentamisin (4.7\%), kombinasi
\end{abstract}


ampisilin sulbaktam dengan gentamisin (4.7\%), kombinasi ampisilin dengan amikasin (4.7\%), kombinasi ampisilin sulbaktam dengan amikasin (4.7\%), kombinasi ceftriaxone dengan $\operatorname{amikasin}(4.7 \%)$.

Kata Kunci: neonatus, antibiotika

\section{PENDAHULUAN}

World Health Organization memperkirakan bahwa secara global terdapat sekitar 5 juta kematian neonatus pertahun. $98 \%$ diantaranya terjadi pada negara-negara berkembang dalam minggu awal kelahiran neonatus. Penyebab utama kematian pada periode neonatus adalah infeksi (32\%) termasuk didalamnya septikemia, meningitis, pneumonia, diare dan tetanus yang diikuti asfiksia kelahiran (29\%) dan prematur (24\%). Infeksi dan penyakit yang disebabkan oleh bakteri, virus, fungi, dan parasit merupakan kejadian yang tidak umum terjadi pada bayi yang baru lahir serta bayi prematur. Infeksi neonatus onset awal terjadi pada 5 hari pertama kehidupannya dan biasanya disebabkan oleh organisme yang diperoleh pada tahap intrauterin dan intrapartum.

Infeksi yang mematikan (disebut juga sepsis neonatorum) terjadi pada $1 \%$ bayi baru lahir dan menyebabkan kematian mencapai 50\%. Rentang waktu antara robeknya membran dan kelahiran diduga sebagai faktor risiko terjadinya infeksi pada ibu dan bayi yang baru lahir, tetapi tidak tergantung pada lamanya persalinan [1].

Kriteria untuk mengidentifikasi bayi yang berisiko terhadap terjadinya infeksi antara lain : usia dalam kandungan ibu $<34$ minggu, berat badan lahir $<2500 \mathrm{~g}, 1$ minute Apgar score $<5$ dan durasi PROM (Premature Rupture Of Membranes) > 72 jam. Semua bayi yang memiliki sejarah ibu PROM selama 18 jam atau lebih harus diobservasi di rumah sakit selama sekurangnya 72 jam. Observasi pada bayi ini penting untuk dilakukan karena sebagian besar bayi yang terinfeksi mengalami gejala dalam $24-48$ jam sejak kelahirannya [1].

Faktor risiko terjadinya infeksi neonatus dalam 72 jam awal kelahirannya dapat diamati dan termasuk didalamnya maternal chorioamnionitis, usia ibu, usi kandungan, PROM, maternal group B streptococcus $(G B S)$ infection, dan bayi yang asupan ASI-nya kurang. Infeksi neonatus onset akhir seringkali disebabkan lingkungan rumah sakit. Kontrol terhadap infeksi nosokomial yang kurang baik, prosedur yang invasif, penggunaan kateter, dan penggunaan antibiotika jangka panjang [2].

Penelitian mengenai sepsis pada neonatus umumnya berfokus kepada organisme penyebab dan pencegahan sepsis, hanya sedikit data yang tersedia mengenai penggunaan antibiotika. Pada negara berkembang, peresepan antibiotika umumnya didasarkan pada pengalaman klinis, hal ini disebabkan keterbatasan fasilitas dan dana. Sebagian besar antibiotika yang digunakan adalah antibiotika spektrum luas dan pola sensitivitasnya belum diketahui.

Penggunaan antibiotika tersebut juga seringkali tidak rasional. Peneliti melakukan studi prospektif yang bertujuan untuk mengevaluasi penggunaan antibiotika di NICU RSAL Dr. Ramelan Surabaya [2]. 


\section{METODE}

Pada penelitian yang dilakukan sejak 26 November 2007 - 26 Januari 2008, 94 pasien (5 pasien neonatus prematur dan 89 pasien neonatus term) diikut sertakan dalam penelitian prospektif observasional ini. Pasien yang diamati merupakan pasien yang mengalami rawat inap di NICU (Neonatal Intensive Care Unit). Data demografis, obat-obat yang digunakan, sejarah kesehatan yang relevan, data laboratorium, kondisi kesehatan dicatat secara prospektif. Penggunaan antibiotika didefinisikan sebagai : 1) terapi yang baru dan / atau 2) perubahan dalam atau penambahan antibiotika baru ke terapi yang telah ada sehingga kemungkinan terdapat lebih dari 1 data antibiotika per neonatus. Setiap perubahan data pemberian antibiotika dihitung sebagai 1 data penelitian.

Pemberian antibiotika awal didefinisikan sebagai pemberian antibiotika dalam 72 jam pertama kelahiran, dan pemberian antibiotika akhir didefinisikan sebagai pemberian antibiotika setelah 72 jam kelahiran. Data hasil penelitian disajikan secara deskriptif melalui tabel.

\section{HASIL DAN PEMBAHASAN}

Sebanyak 94 pasien (5 pasien neonatus prematur dan 89 pasien neonatus term) telah dirawat di neonatal intensive care unit (NICU), semua pasien tersebut disertakan menjadi sampel penelitian. Gambaran karakteristik pasien dapat dilihat pada tabel 1 .

Tabel 1. Karakteristik Pasien

\begin{tabular}{|c|c|c|c|c|}
\hline & \multicolumn{3}{|c|}{ Frekuensi $[\mathrm{N}(\%)]$} \\
\hline & & Prematur & Term & Total \\
\hline \multicolumn{2}{|c|}{ Sampel } & $5(5,3)$ & $89(94,7)$ & $94(100)$ \\
\hline \multicolumn{2}{|c|}{ Laki-laki } & $3(3,2)$ & $58(64,7)$ & $61(64,9)$ \\
\hline \multicolumn{2}{|c|}{ Perempuan } & $2(2,1)$ & $31(33)$ & $33(35,1)$ \\
\hline \multirow[t]{2}{*}{ Usia } & Rentang & $0-1$ hari & $0-17$ hari & $0-17$ hari \\
\hline & Rata-rata & 0,2 hari & 1,45 hari & 1,38 hari \\
\hline \multicolumn{2}{|c|}{ BBLR (Berat Badan Lahir Rendah) } & $4(4,3)$ & $10(10,6)$ & $14(14,9)$ \\
\hline \multicolumn{2}{|c|}{ BMK (Besar Masa Kehamilan) } & $1(1,1)$ & $18(19,1)$ & $19(20,2)$ \\
\hline
\end{tabular}

Semua sampel penelitian mendapatkan terapi antibiotika selama pengobatannya. Kejadian pemberian antibiotika terdokumentasi sebanyak 139 kejadian dari 94 orang neonatus. Enam puluh empat (46 $\%)$ melibatkan antibiotika tunggal dan 75 kejadian (54\%) melibatkan kombinasi 2 antibiotika. Tujuh puluh enam pasien neonatus (80.9\%) menunjukkan asimptomatik dan diterapi secara empirik dikarenakan memiliki risiko tinggi terhadap terjadinya infeksi yang ditandai salah satunya dengan ketuban berwarna hijau keruh / keruh dan / atau KPP > 12 jam. Pada diagnosa akhir hal ini biasanya dinyatakan dengan suspect (S.) infeksi bakteri. Pemeriksaan laboratorium yang standar dilakukan pada pasien neonatus adalah darah lengkap dimana yang diperiksa adalah leukosit, trombosit, $\mathrm{Hb}$, dan differential count. Pada pasien umumnya tidak dilakukan kultur darah.

Pasien neonatus lain $(8.5 \%)$ menunjukkan gejala seperti diare akut maupun gastroenteritis sehingga langsung diberikan antibiotika sesuai dengan gejalanya. Pasien terdiagnosa sepsis umumnya berawal dari kecurigaan klinisi terhadap kondisi neonatus yang tidak mengalami perbaikan dengan pemberian antibiotika empirik, namun terdapat pula pasien neonatus yang 
menjalani rawat inap karena menunjukkan gejala sepsis.

\section{Kejadian Pemberian Antibiotika Tahap Awal (early antibiotic events)}

Antibiotika yang paling sering digunakan sebagai regimen antibiotika empirik adalah kombinasi ampisilin sulbaktam dengan gentamisin $(60.2 \%)$, ampisilin sulbaktam (30.1\%), ceftriaxonee $(6.5 \%)$, kombinasi ampisilin sulbaktam dengan amikasin (1.1\%), kombinasi ampisilin sulbaktam dengan ceftriaxonee (1.1\%), kombinasi gentamisin dengan cetriaxone (1.1\%). Antibiotika empirik tersebut rata-rata diresepkan selama 3 hari. Apabila setelah 3 hari pasien tidak menunjukkan perbaikan kondisi maka antibiotika empirik diatas akan diganti dengan golongan antibiotika lainnya.

\section{Kejadian Pemberian Antibiotika Tahap Akhir (late antibiotic events)}

Antibiotika yang paling banyak digunakan setelah usia kelahiran neonatus $>72$ jam adalah ceftriaxonee (48.4\%), kombinasi ceftriaxonee dengan amikasin (25.6\%), amikasin (9.3\%), ampisilin sulbaktam (4.7\%), kombinasi ceftriaxonee dengan gentamisin $(4.7 \%)$, kombinasi ampisilin sul-baktam dengan gentamisin (4.7\%), kombinasi ampisilin dengan amikasin (4.7\%),kombinasi ampisilin sulbaktam dengan amikasin (4.7\%), kombinasi ceftriaxone dengan amikasin (4.7\%). Kejadian pemberian antibiotika tahap akhir pada penelitian ini tidak hanya dikhususkan pada pasien neonatus yang baru mendapatkan antibiotika setelah usia 72 jam, namun termasuk juga di dalamnya pasien neonatus yang setelah usia 72 jam mendapatkan perubahan regimen antibiotika (sebelumnya telah diberikan antibiotika empirik tahap awal). Antibiotika tahap akhir diresepkan selama
$2-5$ hari. Apabila dalam rentang $2-5$ hari tersebut pasien tidak menunjukkan perbaikan maka antibiotika tunggal dapat diganti atau dikombinasi dengan golongan lainnya (sebagian besar dikombinasi dengan amikasin atau gentamisin).

\section{Pembahasan}

Neonatus yang menjalani rawat inap di NICU RSAL Dr. Ramelan Surabaya sebagian besar dikarenakan neonatus tersebut memiliki risiko tinggi terhadap terjadinya infeksi yang ditandai salah satunya dengan ketuban berwarna hijau keruh / keruh dan / atau KPP > 12 jam, penyebab lainnya adalah diare, gastroenteritis, ikterus, dan sepsis. Pemilihan antibiotika yang digunakan dalam terapi neonatus baik antibiotika tahap awal maupun tahap akhir umunya telah sesuai umumnya telah sesuai dengan pedoman terapi yang berlaku di rumah sakit tersebut.

Masalah-masalah yang timbul terkait dengan penggunaan antibiotika tersebut sebagian besar bersifat potensial dan membutuhkan pengawasan dari tenaga kesehatan yang terlibat di NICU tersebut.

Ampisilin sulbaktam merupakan obat yang paling sering dipakai oleh pasien neonatus di NICU, sekaligus obat yang paling banyak menimbulkan kejadian drug related problems (DRP) efek samping potensial dan satu-satunya obat yang menimbulkan efek samping aktual berupa rash. Obat ini paling banyak digunakan karena ampisilin merupakan antibiotika broad spectrum yang digunakan sebagai terapi profilaksis maupun terapi pemeliharaan pada neonatus yang lahir dengan risiko infeksi [1].

Penggunaan ampisilin sul-baktam sebagai terapi terhadap risiko infeksi pada neonatus sebenarnya belum tercantum dalam 
literatur maupun pedoman terapi, yang disarankan adalah penggunaan ampisilin tunggal [3].

Namun pada beberapa jurnal dilaporkan bahwa mulai terjadi resistensi terhadap antibiotika golongan betalaktam pada neonatus, karenanya kombinasi betalaktam/penghambat betalaktamase memegang peranan penting untuk mempertahankan kegunaan agen betalaktam, salah satu yang disarankan untuk digunakan adalah ampisilin sulbaktam. Sulbaktam sebagai penghambat betalaktamase secara struktur mirip dengan penisilin tetapi mempunyai rantai samping yang dimodifikasi yang memungkinkannya untuk berperan sebagai penghambat, berikatan secara ireversibel dengan betalaktamase dan membuatnya tidak aktif. Oleh karena itu pemecahan antibiotik oleh betalaktamase dapat dicegah dan aktivitas bakterisidal dapat dipertahankan [4].

Penelitian yang dilakukan di Ilorin, Nigeria pada tahun 2002 mengenai bakteri patogen dan pola sensitivitas antibiotika, bakteri gram negatif basili menunjukkan sensitivitas sebesar 69,2\% terhadap ampisilin sulbaktam, organisme gram positif menunjukkan sensitivitas $85 \%$ terhadap ampisilin sulbaktam. Organisme yang paling sering berperan pada sepsis onset awal adalah bakteri gram negatif basili [5].

Gentamisin banyak diguna-kan karena obat ini diindikasikan pemakaiannya sebagai terapi profilaksis pada neonatus yang lahir dengan risiko infeksi.

Penggunaannya dalam penelitian ini telah sesuai dengan pedoman terapi baik dilihat dari segi indikasi, dosis, interval sampai durasi pengobatan [6].
Pada neonatus prematur, klirens gentamisin bergantung pada gestational age, dengan titik potong pada usia 30 minggu. Neonatus yang lebih muda memiliki klirens gentamisin yang lebih rendah, volume distribusi yang sedikit lebih tinggi, dan t1/2 yang lebih lama dibandingkan dengan neonatus yang lebih tua [7].

Berdasarkan teori ini maka neonatus prematur mempunya risiko efek samping terutama nefrotoksik yang lebih besar daripada neonatus term. Amikasin diindikasikan pada neonatus yang mengalami sepsis dengan dosis 7,5 $\mathrm{mg} / \mathrm{kgBB} /$ hari single dose IM atau IV. Amikasin menjadi pilihan setelah pemberian gentamisin dikarenakan amikasin efektif pada infeksi yang disebabkan kuman yang telah resisten terhadap gentamisin. Amikasin memiliki t1/2 yang lebih panjang pada neonatus daripada dewasa normal yaitu $4-5$ jam pada neonatus term berusia lebih atau sama dengan 7 hari dan $7-8$ jam pada bayi dengan berat badan lahir rendah, sehingga neonatus memiliki risiko nefrotoksik yang lebih tinggi [8].

Amikasin secara dominan diekskresi melalui filtrasi glomerolus [9]. Pada penelitian ini amikasin diberikan umumnya diberikan secara IM melalui syringe pump dikarenakan efeknya yang nefrotoksik. Amikasin dalam penelitian ini diberikan selama 5 hari. Pemberian amikasin pada kondisi sepsis sesuai dengan pedoman terapi [6].

Aminoglikosida, seringkali dikombinasi dengan antibiotika beta laktam, secara luas digunakan untuk terapi sepsis pada neonatus. Konsentrasi utama dalam pemebrian aminoglikosida pada neonatus adalah risiko nefrotoksik dan ototoksik [10]. 
Eliminasi dan $\mathrm{t} 1 / 2$ pada neonatus secara umum mengalami penurunan sehingga obat akan lebih lama tinggal di dalam tubuh dan risiko nefrotoksik meningkat. Eliminasi obat yang melibatkan filtrasi glomerular, sekresi tubular dan reabsorpsi tubulur mengalami penurunan pada neonatus prematur, sedangkan nilai filtrasi glomerular pada neonatus term saat lahir 2 kali lebih besar dalam 2 minggu pertama, hal ini menyebabkan neonatus prematur memiliki risiko nefrotoksik yang lebih besar terhadap pemakaian gentamisin dan amikasin.

Efek samping lain dari golongan aminoglikosida yang juga dianggap penting adalah efek ototoksik, yang pada penelitian ini juga tidak dapat dibuktikan kejadiannya karena tidak dilakukan test pendengaran pada neonatus. Namun pada penelitian prospektif mengenai prevalensi gangguan pendengaran pada populasi di neonatal intensive care unit (942 pasien neonatus diamati), pemberian aminoglikosida tidak menjadi faktor risiko yang penting dalam terjadinya gangguan pendengaran terkait komunikasi. Pada sebagian besar kasus lebih banyak disebabkan oleh faktor lain (dysmorphism, prenatal rubella atau cytomegaly, a positie family history of hearing loss, and severe perinatal and postnatal complications) [7].

Ceftriaxone masuk dalam golongan sefalosforin generasi 3 yang memiliki aktivitas yang lebih besar dibandingkan sepalosforin generasi 2 dalam melawan sebagian besar bakteri gram (-). Pada penelitian ini penggunaannya diindikasikan pada infeksi serius dimana penggunaan kombinasi ampisilin sulbaktam + gentamisin selama 5 hari tidak menunjukkan perbaikan klinis atau bila neonatus menunjukkan gejala klinis late sepsis.
Hal ini sesuai dengan pedoman terapi yang ada [6]. Dosis yang umum digunakan adalah $50-100 \mathrm{mg} / \mathrm{kg} /$ hari terbagi tiap 12-24 jam dengan pemberian secara intravena. Bahaya penyebaran penggunaan golongan sefalosporin, terutama ceftriaxone mendapat perhatian khusus dari penelitian serupa mengenai penggunaan antibiotika pada neonatus. Secara in vivo, pembentukan khelat antara kalsium dan ceftriaxone dan peningkatan risiko fungal sepsis pada penggunaan kombinasi sefalosporin secara spesifik terdokumentasi pada neonatus. Anak yang sering terpapar sefalosporin memiliki kecenderungan 6 kali lebih mudah terpapar infeksi ESBLproducing Escherecia coli dan Klebsiella species [11].

Perlu dilakukan penelitian lanjutan untuk membuktikan hu-bungan antara penggunaan ceftriaxone dan peningkatan infeksi tersebut. Namun hal ini dapat menjadi salah satu pertimbangan bagi rumah sakit dan klinisi untuk menyiapkan dan meresepkan obat alternatif untuk ceftriaxone.

\section{KESIMPULAN}

Antibiotika yang digunakan untuk neonatus telah sesuai dengan pedoman terapi yang berlaku di RSAL Dr. Ramelan. Penghentian / penggantian antibiotika yang terjadi lebih awal seringkali dilakukan berdasarkan pertimbangan kesulitan untuk menentukan bakteri penyebab infeksi dan kondisi pasien yang tidak menunjukkan perbaikan.

\section{DAFTAR PUSTAKA}

1. Reuters Health. 2007, Risk factor for deadly newborns infection identified, MedlinePlus. Available

from:http://www.nlm.nih.gov/medlineplus/new s/fullstory_54885.html [cited October 6 2007] 
2. Slogrove, A.L.; Kunneke, H.M.; Engelbrecht, A.; Holgate, S.; Cotton, M.F.; \& Rabie, H. 2010, Evaluating Antibiotic Use In a Secondary Level Hospital Unit in The Western Cape, South Africa, South Afr. J. Epidemiol Infect ;25(3):21-25

3. Naglie, R. 2004, Infectious diseases, In : Neonatalogy Management, Procedures, OnCall Problems, Disease, And Drugs, Fifth Edition, McGraw-Hill Companies, Inc., United States of America, 323-330

4. Adam, D. 2002, Beta-lactam/Beta-lactamase Inhi-bitor Combinations in Empiric Management of pediatric Infections. J. Inter. Medical Research 30 (Suppl 1): 10A - 19A

5. Makuolu, A.O.; Jiya, N.; \& Adesiyun, O.O. 2002, Neonatal septicaemia in Ilorin : bacterial pathogens and antibiotic sensitivity pattern, $A f r$. J. Med. Med. Sci. 31 (2): 127 - 30

6. Harianto,A. 2006, Sepsis neo-natorum, In : Pedoman Diag-nosis \& Terapi Divisi Neonatalogy, Edisi 3, Bag./SMF Ilmu Kesehatan Anak FK UNAIR/RSU Dr. Soetomo, Surabaya, 6-10
7. Aronson, J.K. 2006, Meyler's Side Effects of Drugs, Fifteenth Edition, Elsevier, Amsterdam, 122, 140-145, 1506

8. McEvoy, K.; Snow, E.K.; Kester, L.; Litvak, K.; Miller, J.; \&Welsh, O.H. 2006, AHFS Drug Information Handbook, American Society of Health System, Bethesda, 60, 413.

9. Siddiqi, A.; Khan, D.A. Khan, F. A.; \& Razzaq, A. 2009, Therapeutic Drug Monitoring of Amikacin in Preterm and Term Infants, Singapore Med J; 50(5) : 486

10. Abdel-Hady, E.; Hamamsy, M.E.; Hedava, M.; \& Awad, H. The efficacy and Toxicity of two dosing-regimens of amikacin in neonates with sepsis, J. Clinical Pharmacy and Therapeutics, $2011 ; 36(1): 45-52$

11. Cordero, L.; \& Ayera, L. Duration of Empiric antibiotics for suspected early-onset sepsis in extremely low birth weights infants, In : Evaluating Antibiotic Use In a Secondary Level Hospital Unit in The Western Cape, South Africa, South Afr. J. Epidemiol Infect, 2010, 25(3):21-25 